\title{
Therapeutic Applications of Camel's Milk and Urine against Cancer: Current Development Efforts and Future Perspectives
}

\section{Getachew Alebie $^{1 *}$, Seile Yohannes ${ }^{2}$ and Amha Worku ${ }^{3}$}

${ }^{1}$ Department of Biomedical Science, Jigjiga University, Jijiga, Ethiopia

${ }^{2}$ Department of Genetics, Jigjiga University, Jijiga, Ethiopia

${ }^{3}$ Department of Tropical and Infectious Diseases, Jigjiga University, Jijiga, Ethiopia

\begin{abstract}
The management of cancer in human yet remains a major challenge in contemporary medicine. Natural products have been identified as one of the sources of numerous therapeutic agents. Camel's milk and urine are among such natural products enriched with molecules that are safe to humans and endowed with profound anti-cancer properties. In vitro studies of the anticancer effects of these products are mainly attributed to inhibition of carcinogenesis and mutagenesis, proliferation, and induction of apoptosis. Camel products also showed an improvement in the life span and the survival of animals among the in vivo studies recorded, an effect caused mainly via clearance of malignant tumors in various organs and inhibition of progression to metastasis. Furthermore, prospects of harvesting promising therapeutic nanoparticles/nano-bodies/nano-rods are now being explored from such natural products for cancer therapy. Yet, prominent gap is evident in regard to advanced research geared towards identifying and designing suitable nano-materials. Therefore, a multi-pronged approach entailing a deeper understanding of cancer biology, nanomaterial's molecular characteristics on tumor environment, and further formulation of nano-clones is underscored to position them as clinically useful pharmaceuticals.
\end{abstract}

Keywords: Camel milk; Camel urine; Cancer; Cancer therapy

\section{Introduction}

Cancer, a disease characterized by uncontrolled cellular proliferation and differentiation, remains a worldwide public health concern, with an estimated 14.1 million new cases and 8.2 million deaths having occurred worldwide in 2012, wherein more than $70 \%$ of deaths occurred in low- and middle-income countries (LMIC) [1]. Typical hallmarks of the acquired capabilities of tumor cells during tumorigenesis include: sustained proliferation, evasion of growth suppressors, resisting cell death, replicative immortality, activating invasion, metastasis, evading the immune system, and reprogramming energy metabolism, as well as other features including epigenetic alterations [2-4].

Cancer is caused by exogenous factors, including tobacco, infectious organisms, \& unhealthy diets, as well as endogenous factors such as inherited genetic mutations, hormones, and immune conditions. Such factors may act in concert or in sequence to orchestrate this multifactorial ailment, and due to this complexity of this interaction; ten or more years often pass between exposure to external factors and detection of cancer $[5,6]$.

The management of cancer in humans still constitutes a major challenge for contemporary medicine [7,8]. Albeit the significant amount of progress made thus far with regards to expounding the etiology of cancer to develop a cancer biology framework, the standard antineoplastic therapies available rely primarily on surgery, chemotherapy, radiotherapy, hormone therapy, and immunotherapeutic approaches [9]. As any golden standard treatment regime are those which could selectively kill the malignant cells whilst sparing healthy tissues and vital organ function unlike the available treatment schemes, this shows that they are still far from being ideal $[10,11]$. Chemotherapy is, in particular, the primary treatment mode at different stages for a wide range of cancer types albeit being characterized by high toxicity, long lasting side effects, morbidities, and even potential lethality $[12,13]$.

Such drawbacks underscore on the dire need to intensify the strides to develop alternative treatment and/or management regimes that are less evasive and with minimal side-effects. One of the best known paths to be followed therein to in pursuit of better cures relates to research on natural products. Natural products have long been recognized as important sources of therapeutically effective substances, with the majority of the world's population relying almost entirely on natural products for medication. Their use has been reborn following a diminished utility these past few decades, with advanced technologies as high-throughput screening \& combinatorial chemistry having taken the center stage in drug discovery.

A notable point regarding natural products in cancer treatment, of the $121 \mathrm{FDA}$ approved prescription drugs in use its treatment, 90 are derived from plant species, and more striking are the fact that $74 \%$ of such drugs were discovered by investigations following a folklore claim $[14,15]$. Further, as the currently available therapeutic approaches lack specificity for the particular cancer cells, a strict necessity of searching for novel anticancer therapeutics with desired characters from the popular realm of natural remedies in ethno-medicine has been underscored. One such source of promising organic substances with profound health benefits \& therapeutic values refers to products and byproducts of the dromedary camel, namely camel milk and camel urine [16].

\section{Anticancer Effects of Camel's Milk and Urine}

Management of cancer is one of the major challenges in medical practice as there are no available medical modalities that can selectively

*Corresponding author: Getachew Alebie, Department of Biomedical Science, Jigjiga University, Jijiga, Ethiopia, Tel: 0913358247; E-mail: gechalebie@gmail.com

Received April 02, 2017; Accepted May 02, 2017; Published May 09, 2017

Citation: Alebie G, Yohannes S, Worku A (2017) Therapeutic Applications of Camel's Milk and Urine against Cancer: Current Development Efforts and Future Perspectives. J Cancer Sci Ther 9: 468-478. doi: 10.4172/1948-5956.1000461

Copyright: @ 2017 Alebie G, et al. This is an open-access article distributed under the terms of the Creative Commons Attribution License, which permits unrestricted use, distribution, and reproduction in any medium, provided the original author and source are credited. 
Citation: Alebie G, Yohannes S, Worku A (2017) Therapeutic Applications of Camel's Milk and Urine against Cancer: Current Development Efforts and Future Perspectives. J Cancer Sci Ther 9: 468-478. doi: 10.4172/1948-5956.1000461

kill cancer cells without any adverse effect on normal living cells or the functions of vital organs. Chemoprevention by dietary constituents in the form of functional food has a well-established beneficial role in health promotion and emerged as a novel approach to control disease like cancer [17].

Camel milk is among such dietary supplement with profound nutraceutical values. From medicinal value point of view, it has a rich content of protective minerals and proteins that could have vital role for enhancing immune defense mechanism [18]. It contains higher amount of zinc which offer significant role in the development and maintenance of a normally functioning immune system [19]. Camel milk has insulin like activity, regulatory and immunomodulatory functions on $\beta$ cell. It contains good amount of protective proteins, including lysozme, lactoferrin, lactoperoxidase, peptidoglycan recognition protein (PGRP) enzyme, immunoglobulin G, and secretory immunoglobulin A. These immune factors are present at greater concentrations in camel milk [20].

Despite waste product, camel urine has been also used as a source for many therapeutic agents [21]. It contains various complex bioactive compounds that could act against carcinogenic agents [22]. Drinking camel urine is shown to be effective in treating numerous cancers in human (Figure 1) [23].

\section{Safety Profile}

The safety assessment of drug compounds is the primary step to be done for its therapeutic use in humans. Several drugs have been withdrawn from the market due to the severe adverse effects in patients [24-26]. Most of these drugs have shown potential to cause toxicity in healthy organs such as hepatotoxicity and nephrotoxicity [27-29]. On the other hand, camel's milk (CM) is an excellent source of wellbalanced nutrients and serves as the main source of food. It exhibits a range of biological activities that influence digestion, metabolic responses to absorbed nutrients, growth and development of specific organs and resistance to diseases [30,31].

Camel urine is a rich source of natural by-product with no harmful health effect in human. Compounds, such as ammonia and urea known to offer bad smell and toxicity of urine in human and all other animals are lacking or minimal in camel urine. Other distinguishing features of camel urine include; it contains about ten folds more mineral salts than human urine, it is basic with a $\mathrm{pH}$ value of 7.8 while human urine is acidic [32].

Numerous preclinical and clinical-based investigations have been done thus far on the safety profile of camel's urine components (PM701, bioactive fraction (PMF) and its sub-fraction (PMFK)). As a result, it has found to be safe to human use as no change in the architectures and hepatotoxic, nephrotoxic effects and any hematological toxicity were observed under all experimental conditions used [9,33-35]. Notably, these components are found to activate the immune system through enlarging the germinal centers of the white pulp lymph nodules in the spleen [9].

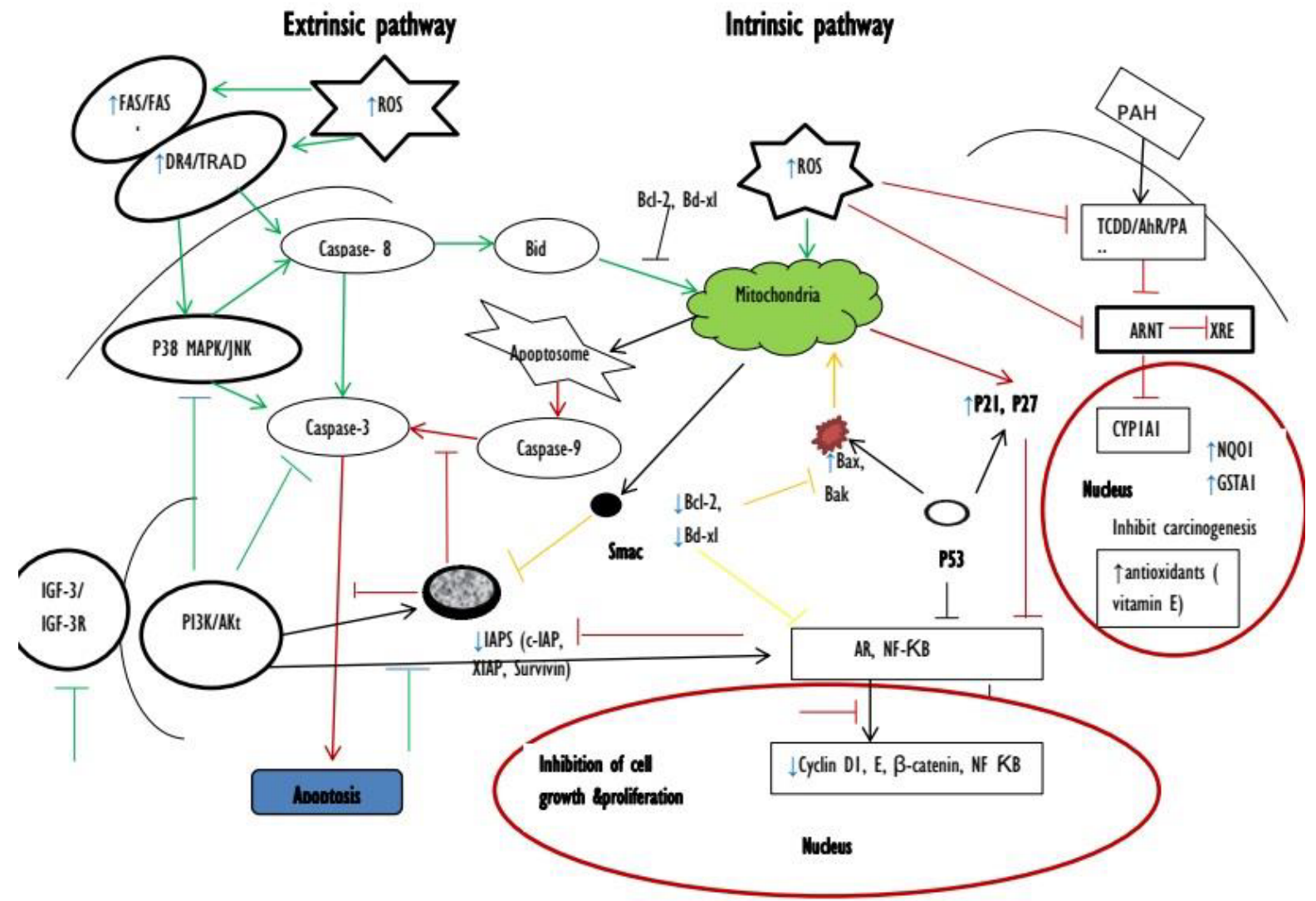

Figure 1: Anticancer effect of camel's milk and urine (CM \& CU). CM \& CU induce apoptosis in various cancer cells through extrinsic pathway by enhancing DR4 expression and ROS production, causing activation of JNK and caspases and intrinsic pathways mainly by enhancing ROS production that lead to activation of caspases. Inhibit carcinogenesis by down-regulating the induction of Cyp1a1, a cancer activating gene, and inducing Nqo1 and Gsta1, cancer protecting genes. Inhibit Cell cycle progression, proliferation and survival of cancer cells by interfering on binding of insulin-like growth factor receptor, a known regulator of the phosphatidylinositol 3-kinase/Akt pathway as well as activation of caspases, causing increase in cyclin-dependent kinase (CDK) inhibitor p21 and p27 protein levels. Activation by CM (green), CU (yellow), CM \& CU (red); inhibition by CM (green), CU (yellow), CM \& CU (red); $\uparrow$ increase, $\downarrow$ decrease. 
Citation: Alebie G, Yohannes S, Worku A (2017) Therapeutic Applications of Camel's Milk and Urine against Cancer: Current Development Efforts and Future Perspectives. J Cancer Sci Ther 9: 468-478. doi: 10.4172/1948-5956.1000461

\section{Cytotoxic Effect}

It is of primary importance to find an anticancer agent that kills cancer cells without un-acceptable toxicity to patient's own tissues and overall functions. Both camel milk and urine are among natural products endowed in agents with such desirable characteristics. These products possess supreme cytotoxic effect against various cancer cells and cell lines (Table 1) [9-11,16, 23, 36-51].
Camel products could exert cytotoxic activity against cancer cells through different mechanisms while inhibition of carcinogen-activating genes signaling pathways is well understood in this regards. Camel's milk and urine are recognized to significantly inhibit the induction of a cancer-activating gene (Cyp1a1), and to induce cancer protecting genes (Nqoland Gsta1) in several lines of cancer cells at the mRNA, protein and activity levels. These products mediate CYP1A1 inhibition at

\begin{tabular}{|c|c|c|c|c|c|}
\hline Experimental Model & $\begin{array}{l}\text { Stage of } \\
\text { validation }\end{array}$ & $\begin{array}{l}\text { Camel product/ } \\
\text { byproduct } \\
\text { (compounds) }\end{array}$ & Dose and time & Major effects/mechanisms of action & References \\
\hline Healthy humans & $\begin{array}{l}\text { Clinical trial } \\
\text { (healthy } \\
\text { volunteers) }\end{array}$ & CU (PM 701 capsule) & $\begin{array}{l}3-10 \text { capsules ( } 300 \mathrm{mg} \\
\text { capsule }^{-1} \text { ) daily for } 4 \text { months }\end{array}$ & $\begin{array}{l}\text { Safe in healthy volunteers/no adverse effect in vital } \\
\text { organs }\end{array}$ & [9] \\
\hline $\begin{array}{l}\text { Mice leukemia (L1210) } \\
\text { cell }\end{array}$ & In vitro & CU (PM-701) & $16 \mathrm{mg} / \mathrm{ml}$ for $0-72 \mathrm{~h}$ & $\begin{array}{l}\text { Control tumor progression, metastasis and prevent } \\
\text { recurrence }\end{array}$ & [11] \\
\hline Lung cancer cells (A549) & In vitro & CU (PM-701) & - & $\begin{array}{l}\text { Inhibition of cell proliferation (Magateer } \\
\text { breed>Majaheem with respect to age and sex) }\end{array}$ & [16] \\
\hline $\begin{array}{l}\text { Murine hepatoma Hepa } \\
1 \mathrm{c} 1 \mathrm{c} 7 \text { cell line }\end{array}$ & In vitro & $\begin{array}{l}\text { CU (Virgin, lactating and } \\
\text { pregnant ) }\end{array}$ & & $\begin{array}{l}\text { Inhibition of the TCDD-mediated toxic } \\
\text { effect/ } \downarrow \text { expression of Cyp } 1 a 1 \text {, at the mRNA and } \\
\text { protein expression levels }\end{array}$ & [23] \\
\hline Healthy mice & In vivo & $\mathrm{CU}$ (PMF) & $\begin{array}{l}2-20 \times \text { of therapeutic dose } \\
(0.75 \mu \mathrm{l})\end{array}$ & $\begin{array}{l}\text { Safe in mice/has not any hepatotoxicity and } \\
\text { nephrotoxicity }\end{array}$ & [33] \\
\hline Healthy mice & In vivo & CU (PMF) & $\begin{array}{l}2-20 \times \text { of therapeutic dose } \\
(0.75 \mu \mathrm{l})\end{array}$ & $\begin{array}{l}\text { safe in mice/has not any hepatotoxicity and } \\
\text { nephrotoxicity }\end{array}$ & [34] \\
\hline Healthy mice & in vitro & CU (PM 701) & $10 \mathrm{~g} \mathrm{~kg}^{-1}$ for 4 weeks & $\begin{array}{l}\text { safe in mice/has not any hepatotoxicity, } \\
\text { nephrotoxicity and hematological toxicity }\end{array}$ & [35] \\
\hline $\begin{array}{l}\text { Murine hepatoma Hepa 1c1c7 } \\
\text { cell line }\end{array}$ & In vitro & $\mathrm{CM}$ & $\begin{array}{l}5 \text { and } \\
100 \mu \mathrm{L} / \mathrm{mL}\end{array}$ & $\begin{array}{l}\text { Inhibition of carcinogenesis and mutagenesis/ } \\
\text { modulation of AhR-regulated genes; } \uparrow \text { Ho- } \\
1, \text { Nqo1 and Gsta1 at the transcriptional and } \\
\text { posttranscriptional levels; } \downarrow \text { TCDD-mediated } \\
\text { induction of Cyp1a1 activity, Cyp1a1 mRNA, protein }\end{array}$ & [36] \\
\hline Hepatocellular carcinoma & In vivo & $\mathrm{CM}$ & $5 \mathrm{ml}$ up to 38 weeks & Inhibit hepatic carcinogenesis & [37] \\
\hline $\begin{array}{l}\text { Colon cancer cell line (HCT-116) } \\
\text { cell lines }\end{array}$ & In vitro & CM (lactoferrin) & - & $\begin{array}{l}\text { Anti-proliferation effect } \\
\text { Inhibit DNA Damage and exert antioxidant activity }\end{array}$ & [38] \\
\hline $\begin{array}{l}\text { Human lung cancer } \\
\text { cells (A549) }\end{array}$ & In vitro & CU (PM 701) & $\begin{array}{l}-3(10-3) \\
\text { PM701 for } 24 \mathrm{~h}\end{array}$ & Selectively kill cancer cells & [39] \\
\hline $\begin{array}{l}\text { Human lung cancer cells (A549), } \\
\text { Mice's leukemia cells } \\
\text { (L1210) }\end{array}$ & In vitro & CU (PM 701) & -5 to -2 PM701; 24-96 h & $\begin{array}{l}\text { Selective anti-cancer activity } \\
\text { Apoptotic effect/damage the cell nuclei, limiting the } \\
\text { division of cells, causing degradation in apoptotic } \\
\text { manner }\end{array}$ & [40] \\
\hline $\begin{array}{l}\text { Mice's leukemia cells } \\
\text { (L1210) }\end{array}$ & $\begin{array}{l}\text { In vitro } \\
\text { In vivo }\end{array}$ & CU (PM 701) & $\begin{array}{l}-3\left(10^{-3}\right) \\
\text { PM701 for } 24 \mathrm{~h} \\
-3\left(10^{-3}\right) \\
\text { PM701 after } 7 \text { days of } \\
\text { treatment }\end{array}$ & $\begin{array}{l}\text { Apoptotic effect/damage the cell nuclei } \\
\text { Antimitotic effect/inhibit tumor progression }\end{array}$ & [41] \\
\hline $\begin{array}{l}\text { Human hepatocellular carcinoma } \\
\text { (HEPG2), colon carcinoma (HCT } \\
116) \text { and glioma (U251) cell lines }\end{array}$ & In vitro & $\begin{array}{l}\text { CU (PMFand its } \\
\text { subfractions (M2-M8)) }\end{array}$ & $-1,2.5,5,10 \mu \mathrm{g} / \mathrm{ml}$ & Cytotoxic effects & [42] \\
\hline Lung cancer cells (A549) & In vitro & $\begin{array}{l}\text { CU (PM701,PMF, } \\
\text { PMFK) }\end{array}$ & $2-20 \mu \mathrm{g} / \mathrm{ml}$ for $24,48,72 \mathrm{~h}$ & Cytotoxic activity and inhibition of proliferation & [43] \\
\hline Lung cancer cells (A549) & In vitro & $\mathrm{CU}(\mathrm{PMF})$ & - & $\begin{array}{l}\text { Induction of apoptosis/caused biochemical changes } \\
\text { such as protein, lipid and nucleic acid structures }\end{array}$ & [44] \\
\hline Lung cancer cells (A549) & In vivo & $\mathrm{CU}$ (PMF) & - & $\begin{array}{l}\text { Induction of apoptosis } / \uparrow p H, \text { caused biochemical } \\
\text { changes such as protein, lipid and nucleic acid } \\
\text { structures }\end{array}$ & [45] \\
\hline Breast cancer cell (MCF-7) & In vitro & $\begin{array}{l}\text { CU (PM701,PMF, } \\
\text { PMFK) }\end{array}$ & $\begin{array}{l}2-20 \mu \mathrm{g} / \mathrm{ml} \text { for } 24,48,72 \\
96 \mathrm{~h}\end{array}$ & $\begin{array}{l}\text { Inhibition of proliferation } \\
\text { Induction of apoptosis }\end{array}$ & [46] \\
\hline $\begin{array}{l}\text { Breast carcinoma, colorectal } \\
\text { cancer cells, glioma cells, liver } \\
\text { carcinoma, leukemia cells, } \\
\text { lung cancer cells }\end{array}$ & In vitro & $\begin{array}{l}\mathrm{CU} \\
(\mathrm{PMF})\end{array}$ & $\begin{array}{l}0.5-2.0 \mathrm{mg} / \mathrm{mL} \text { for } 4 \text { and } \\
8 \text { days }\end{array}$ & $\begin{array}{l}\text { anti-cancer effects by increasing apoptosis and } \\
\text { altering cellular metabolic activity }\end{array}$ & [47] \\
\hline Rodent's Lung Cancer & In vivo & $\mathrm{CU}$ (PMF) & $\begin{array}{l}120 \mathrm{mg} \text { PM/kg/day; } 4-6 \\
\text { months }\end{array}$ & Anti-neoplastic effect but with long time treatment & [48] \\
\hline $\begin{array}{l}\text { Human hepatoma HepG2 } \\
\text { and breast cancer MCF7 cells }\end{array}$ & In vitro & $\mathrm{CM}$ & 20 and $76 \mathrm{mg} / \mathrm{mL}$ & $\begin{array}{l}\text { Inhibition of proliferation and growth } \\
\text { Induction of apoptosis/through apoptotic- and } \\
\text { oxidative stress-mediated mechanisms; } \uparrow D R 4 \\
\text { mRNA, intracellular ROS, JNK activation of } \\
\text { caspase-3 mRNA and } \downarrow \text { ERK }\end{array}$ & [49] \\
\hline
\end{tabular}




\begin{tabular}{|c|c|c|c|c|c|}
\hline $\begin{array}{l}\text { Breast cancer (MDA-MB-231, } \\
\text { MCF-7), breast epithelial cells } \\
\text { (MCF 10A), Medulloblastoma } \\
\text { cells (DAOY, MED-4, MED-13 } \\
\text { and MED-8), osteosarcoma } \\
\text { (U2OS), and the colon cancer } \\
\text { (LoVo and HCT-116) cells }\end{array}$ & In vitro & $\mathrm{CU}$ & $16 \mathrm{mg} / \mathrm{ml}$ for $0-72 \mathrm{~h}$ & $\begin{array}{l}\text { Selective cytotoxic effect } \\
\text { Inhibition of proliferation } / \uparrow \text { cyclin dependent kinase } \\
\text { inhibitor } \mathrm{p} 21, \downarrow \text { b-catenin and cyclin D1 } \\
\text { Induction of apoptosis/ } \downarrow \text { Bcl- } 2, \uparrow \text { Bax, active cleaved } \\
\text { caspase } 3 \\
\text { Immune modulatory effect } / \uparrow \text { inflammatory cytokines }\end{array}$ & [50] \\
\hline $\begin{array}{l}\text { Human cancer cells (A549, } \\
\text { HCT116, HepG2, MCF-7, U251 } \\
\text { and Hela) }\end{array}$ & In vitro & $\begin{array}{l}\mathrm{CU} \text { (new PMF with large } \\
\text { and } \\
\text { small molecule) }\end{array}$ & $1-10 \mu \mathrm{g} / \mathrm{ml} 48$ and $72 \mathrm{~h}$ & Effective and selective anti-cancer properties & [51] \\
\hline $\begin{array}{l}\text { Human breast } \\
\text { cancer cell (BT-474) }\end{array}$ & In vitro & Lyophilized CM & $2.5-30 \mathrm{mg} / \mathrm{mL}$ for $24 \mathrm{~h}$ & $\begin{array}{l}\text { Repressed cells growth and proliferation/initiation of } \\
\text { the intrinsic and extrinsic apoptotic pathways }\end{array}$ & [88] \\
\hline HepG2 and HeLa cell lines & In vitro & $\begin{array}{l}\text { CM } \\
\text { (Casein) }\end{array}$ & $\begin{array}{l}0.5-2.0 \mathrm{mg} / \mathrm{mL} \text { for } 4 \text { and } \\
8 \text { days }\end{array}$ & $\begin{array}{l}\text { casein (with } \alpha \text {-lactalbumin) initiate cellular apoptotic } \\
\text { cascade }\end{array}$ & [89] \\
\hline
\end{tabular}

Table 1: Anti-cancer properties and safety profiles of camel milk, urine and extracted compounds demonstrated at preclinical and clinical levels.

transcriptional level through AhR-dependent transcriptional control. This is attributed to AhR antagonistic effect of these products and subsequent inhibition of Cypla1 induction by TCDD. In in vitro study, urine of virgin camel but not pregnant and lactating camel efficiently bound to and inhibited the transformation of cytosolic AhR to a DNAbinding form [23], necessitating to assess binding and affinity of ligand to the AhR [52]. Regarding translational level effect, these natural camel products inhibit TCDD-mediated translation of Cyp1a1 mRNA into a functional protein. Furthermore, Cyplal catalytic activity can be altered through several posttranslational mechanisms, such as phosphorylation, proteasomal degradations, and modulation of $\mathrm{HO}-1$ gene expression [53,54]. HO-1 gene expression, a rate-limiting enzyme in heme catabolism, is found to alter cellular heme, the prosthetic group of CYP450, content and hence the enzyme activity [55]. Evidently, camel milk (fat-free) was found to induce the expression of Ho-1 mRNA and decreased the Cypla1 activity levels by degrading its heme content [36].

Meanwhile, camel's milk and urine are able to increase the expression of chemo-protective genes, Nqo1 and Gsta1 mRNA levels pertaining to increase the levels of several antioxidant enzymes which prevent the formation of highly reactive oxygen radicals and then protect DNA adduct and cell damage $[23,38,56]$. In addition, over expression of Nqo1 in several human solid tumors and cancer cells is shown to activate bio-reductive chemotherapeutic agents in tumor cells that allow tumor cytotoxicity without corresponding toxicity to normal cells [57].

Various mediators in camel milk are implicated to offer such cytotoxic property against different cancer cells. These include: antioxidant vitamins, such as vitamin E and C [58], casein, lactoferrins, fatty acids, immunoglobulines and various trace elements [23,59]. High level of vitamin C in camel milk offered nucleophilic, anticlastogenic and antimutagenic role [60-65]. Selenium and zinc protect against the genotoxic effect of toxic compounds [66-69]. Casein and its product formed during pepsin hydrolysis protect mammalian cells against certain genotoxic compounds [70-72]. Lactoferrin is an important iron-binding glycoprotein possesses immune-inducing and immunomodulatory properties thereby exert antitumor activity [7375]. Conjugated linoleic acid (CLA) serve as useful food antioxidants and inhibit activation of carcinogen by opposing direct interaction of procarcinogen, scavenging of electrophiles or selective induction of phase I detoxification pathways [76-81]. Selenium is a constituent of various oxidant defense selenioproteins and a cofactor of glutathione peroxidase in the elimination of peroxide radicals and hence prevents cancer development. Zinc plays pivotal role during DNA and RNA synthesis and serve as a cofactor in superoxide dismutase activity [82].

\section{Apoptotic Effect}

Apoptosisis a physiological cellular process of cell death initiate by wide variety of extrinsic and intrinsic signals and stimuli [83]. These signals instruct the cells to undergo apoptosis through the activation of a family of proteins known as caspases. The intrinsic signals initiate apoptosis through mitochondrial oxidative stress caused by free radicals [84] while the extrinsic signals induce apoptosis through binding of cell surface death receptors, such as tumor necrosis factor (TNF) receptor 1 (TNFR-1), TNF related apoptosis-inducing ligand receptor 1 (TRAILR-1), death receptor (DR4, and DR5) [83-85]. Signals in both pathways activate effector caspases such as caspase-3 [86]. Apoptosis is an important phenomenon in chemotherapy-induced killing of tumor cells as many anti-cancer drugs and natural products act through the induction of apoptosis to prevent tumor promotion and progression (Table 1) [87]. Camel's milk and urine induce apoptosis in various cancer cell lines through activating both extrinsic and intrinsic apoptotic pathways (Table 1) $[49,88,89]$. It would induce apoptosis through activation of caspase- 3 at mRNA and activity levels. Camel milk significantly induces the expression of DR4 and oxidative stress marker (HO-1) mRNA, and enhances ROS production, thus mediate apoptotic cell death through both extrinsic and intrinsic apoptotic pathways. Recent findings have been shown that camel milk-mediated caspase-3 mRNA expression is associated with MAPK cascades, which play important roles in cell death and survival signaling $[90,91]$. Importantly, inhibition of JNK and p38 MAPK has significantly decreased activation of caspase-3 mRNA in response to camel milk [92], can be suggested that both kinases pertain proaptotic effect. Moreover, lyophilized camel's milk is found to differentially initiate apoptosis in BT-474 and HEp 2 cell lines as estrogen receptor-mediated apoptosis is performed in the former cell line whereas an alternative non-estrogen receptors pathway could mediate apoptosis in HEp 2 cell line [88].Thus, further investigation is required to understand the receptor involved on camel milk mediated apoptosis in the later cell line. Overall, the exact potential mediator of camel milk involved in apoptosis is not well known, but $\alpha$-lactalbumin purified from camel casein is found to initiate apoptosis cascade in HepG2 and HeLa cells [89].

Meanwhile, many line of evidences revealed that different forms of camel urine, including PM701, PMF and PMFK significantly induced apoptosis in several cancer cell lines (Table 1) [40-50]. The possible mechanisms suggested include; decreasing Bcl-2, downregulating the expression of several cancer-related genes such as b-catenin, cyclin D1, and the anti-apoptotic survivin protein.

\section{Anti-proliferative Effect}

The anti-cancer effect of Camel's milk and urine is not only 
attributed to cytotoxic and anti-apoptotic characteristics but also the anti-proliferative effect. Those camel products caused potent anti-proliferative effect on various cancer cell lines, largely through apoptotic and oxidative stress-mediated mechanisms (Table 1) $[16,38,43,46,49,50,88]$. Lactoferrin is an important camel milk component which is well studied in this regards. Lactoferrin inhibit the proliferation of cancer cells by various mechanisms. One of such mechanism includes that it interacts with polysaccharides ligands on cell surfaces and activate cell signaling pathways such as the Fas pathway thereby inhibit the growth of tumor by apoptosis [93]. Lactoferrin can also penetrate cells and function as a transcription factor and activating the transcription of specific DNA sequences $[38,94]$. Moreover, lactoferrin down-regulate cell proliferation through growth arrest at the $\mathrm{G} 1$ to $\mathrm{S}$ transition of the cell cycle and induce an increase in cyclin-dependent kinase (CDK) inhibitor $\mathrm{p} 21 \mathrm{cip} 1$ protein levels through a p53-independent mechanism [95,96]. Its effect on cell cycle can be attributed to; decrease in pAkt, increase in p27, and a reduction in cyclinE and $\mathrm{pRb}$ protein levels. Lactoferrin is found to bind with insulin-like growth factor-binding protein-3 [97], thereby act by altering the availability or stability of insulin-like growth factor, a known regulator of the phosphatidylinositol 3-kinase/Akt pathway [98].

Accordingly, camel urine possess supreme anti-proliferative effect on many lines of cancer cell possibly through the induction of the cyclin dependent kinase inhibitor p21 as it is found to up-regulates p21 in the p53-defective cancer cells $[39,99]$. Anti-proliferative effect of camel urine is significantly influenced by breeds, age, sex and other camel characteristics. In vitro study conducted by Alghamdi and Khorshid to understand the effect of urines obtained from Magateer and Majaheem camels of different age and sex groups on the growth of lung cancer cells (A549) showed that urine obtained from young and adult Magateer significantly down-regulate proliferation of cancer cells than their respective encounter breed. Importantly, urine obtained from adult male Magateer showed substantial anti-proliferative effects in lung cancer cells. Despite such outstanding study, the potential bioactive ingredients responsible for the observed variations is not examined, and hence further investigation aimed at identifying entailed agents is underscored in this line.

\section{Camel's Milk and Urine Nanoparticles}

Nanomedicine becomes an emerging discipline entailing production of varieties of nanoparticles for different medical applications, including for the treatment of disease, diagnosis, monitoring, and control of biological systems [100]. Importantly, entailed problems associated with targeting particular cells or body systems and degradability by various body systems such as lytic enzymes and extreme $\mathrm{pH}$, and subsequent need of high dose, led currently prescribed drugs to be less effective and to cause toxic effect in the patients. On the other hand, the emergence of nanotechnology pertains to produce varieties of nanoparticles capable of targeting particular cells or body systems thereby contributing to efficient antigens/proteins/drugs/oligonucleotides delivery and thus required lower dosage. NPs can act as both carriers and adjuvants, hence removing the need for conventional adjuvants altogether [101].

In light of this, camel's milk and urine are natural products endowed with numerous agents suitable for such applications. Camel's milk phospholipids, such as phosphatidyl-ethanolamine (PE), phosphatidyl-choline (PC), lysophosphatidylcholine (LPC) and phosphatidylinositol (PI); proteins, including immunoglobulin are among well studied molecules in this regards [102]. Camel milk has unique immunoglobulin called the $\mathrm{VHH}$ (variable heavy heavy) antibodies or nanobodies devoid of the typical light chains present in normal antibodies. This offers camel antibodies much smaller in size as compared to the normal antibodies and pertaining to increase tissue penetration while retaining the specificity [103,104]. Camel IgGs (which also exist in the milk, besides being present in blood) are able to penetrate within tissues unlike human IgGs. Therefore, they can enter inside the cells where they would perform various functions under pathological conditions (Table 2) [105-107].

Camel urine is rich in many organic and inorganic compounds. PMF and PM701 of camel urine possess different nanoparticles, crystals and nano-rods with varying shapes and sizes. PMF crystals contain various compounds such as calcium oxalate, cystine, tyrosine, uric acid crystals, ammonium urate, calcium phosphate, hippuric and benzoic acids $[108,109]$. El-Shahawy et al. [110] detected the presence of glycine, alanine, and arginine in PMF. It also contain several ions, but $\mathrm{Cs}, \mathrm{Rb}, \mathrm{K}, \mathrm{Ca}, \mathrm{Cd}, \mathrm{Y}, \mathrm{Eu}, \mathrm{Th}$ and $\mathrm{Zn}$ are present in relatively high concentration. Zinc is present in the form of $\mathrm{ZnO}$ and $\mathrm{Ca}, \mathrm{Cd} \& \mathrm{Y}$ are in the form of sulfates (Table 2) [108,109].

The aforementioned components of PMF offer potent selective cytotoxic activity against several lines of cancer cells. Mechanistically, macro and nanoshells of PMF which contain different type of metals such as $\mathrm{K}+, \mathrm{Ca} 2+, \mathrm{Eu}+3$ attack cancer cell membrane by influencing on the permeability of the membrane. There are few clinically approved nanocarriers that incorporate molecules to selectively bind and target cancer cells [111]. Glycine and other amino acids remarkably offer unique selectivity of various PMF elements to cancer cells, hence can be utilized for many applications. $\mathrm{ZnO} \mathrm{NP}$ is one of the most important metal oxide nanomaterials due to its various medicinal use and biological applications. Notably, its selective cytotoxic effect on cancer cells is among its important features in this regard [112,113]. NPs induced ROS generation and consequent OS is frequently observed and is the most discussed paradigm for NP toxicity [114,115]. Cytotoxic potential of $\mathrm{ZnO}$ is attributed to many features, including induction of oxidative stress through generation of ROS on the surface of particles [115-117], dissolution and release of $\mathrm{Zn} 2+$ ions and physical interaction of $\mathrm{ZnO}$ NPs with the membrane wall cause deformation and rupture of membrane [118]. In addition to these NPs, Cs- and Rbcan specifically enter cancer cells and embryonic cells but not normal adult cells $[119,120]$. PMF contain 70.9128 and 8.04 ppm Rb and Cs respectively and thus may indicate the selectivity action of this new anticancer agent (PMF). Cs and $\mathrm{Rb}$ nanoparticles of PMF selectively attack cancer cells by elevating the $\mathrm{pH}$ [111]. Cd and Y of PMF are the core of nanoshell, and have high magnetic property thereby enhance its selective cytotoxicity against various cancer cells $[44,111]$.

Numerous amino acids of PMF regulate various functions in normal cells and in oncogenesis. Receptor tyrosine-specific protein kinases are a subclass of cell-surface growth-factor receptors with an intrinsic, ligand-controlled tyrosine-kinase activity, and they are important target because they play an important role in the modulation of growth factor signaling [121]. Meanwhile, presence of tyrosine enhances the efficiency and selectivity of PMF on cancer cells. Glycine and cysteine, amino acids entering to glutathione structure, enhance its antioxidant activity and further improve the immune system [122]. Arginine has immunomodulatory effects, such as stimulating T- and natural killer cells activity, and influencing pro-inflammatory cytokine levels through activating interleukin-12 (IL-12) [123]. It also induces IL-23 that leads to the production of interferons (IFNs) and other tumor-suppressive factors. These molecules are activated as part of the antitumor immunity response and promote apoptosis to tumor cells [124]. 
Citation: Alebie G, Yohannes S, Worku A (2017) Therapeutic Applications of Camel's Milk and Urine against Cancer: Current Development Efforts and Future Perspectives. J Cancer Sci Ther 9: 468-478. doi: 10.4172/1948-5956.1000461

\begin{tabular}{|c|c|c|c|c|c|}
\hline Active compounds & Dose & Cancer cell (cell lines) & Major effects/mechanisms of actions & Status & References \\
\hline a-lactalbumin & 0.5 and $2.0 \mathrm{mg} / \mathrm{mL}$ & $\begin{array}{l}\text { Liver and blood cancer } \\
\text { (HepG2 and HeLa cells) }\end{array}$ & Induce Apoptosis & In Vitro & [105] \\
\hline $\begin{array}{l}\text { PMF nanoparticles; } \mathrm{Zn}, \mathrm{Ag}, \mathrm{Y}, \mathrm{Cs}, \mathrm{Rb} \text { and } \\
\text { hippuric and benzoic } \\
\text { Acids. Mainly a nanoshell of Glycine }\end{array}$ & $\begin{array}{l}\text { PMF added to the } \\
\text { ordinary media with } \\
\text { ratio } 2.5 \mu \mathrm{g}: 1 \mathrm{ml} \\
\text { media }\end{array}$ & lung cancer cells (A549) & $\begin{array}{l}\text { Induction of apoptosis/attack the nuclear } \\
\text { membrane and the other cell organelles } \\
\text { resulting completely paralyzing the cells }\end{array}$ & In vitro & [108] \\
\hline $\begin{array}{l}\text { PMF701nanoparticles } \\
\text { Tyrosine, Glycine, } \\
\text { Cyctine, arginine, hippuric and benzoic } \\
\text { acids and } \mathrm{ZnO} \text { nanoparticles }\end{array}$ & - & Lung cancer ( A549) & $\begin{array}{l}\text { Apoptosis/Glycine-attack nuclear membrane } \\
\text { and other organelles after being engulfed by } \\
\text { cancer cells-which are addicted to it hence } \\
\text { provide heavy nanoparticles to enter and } \\
\text { degenerate the mitochondria of cancer cell } \\
\text { through apoptosis }\end{array}$ & In Vitro & [109] \\
\hline $\begin{array}{l}\text { Chlorine and Bromine elements in PMF-G } \\
\text { and amino acids such astheronine, } \\
\text { cysteine, tyrosine and ethionine which } \\
\text { are very important for damage the } \\
\text { proliferated cancer cells. }\end{array}$ & - & lung cancer cells (A549) & $\begin{array}{l}\text { anti-proliferate effect and apoptotic effect/bind } \\
\text { OGF (opiod growth factor ) and repress cell } \\
\text { replication }\end{array}$ & In vitro & [110] \\
\hline $\begin{array}{l}\text { PMF (Cesium (Cs) and Rubidium (Rb) } \\
\text { nanoparticles) }\end{array}$ & $2.5 \mu \mathrm{g} / \mathrm{ml}$ up to $30 \mathrm{~min}$ & $\begin{array}{l}\text { human lung cancer cells } \\
\text { (A549) }\end{array}$ & $\begin{array}{l}\text { Induction of apoptosis/caused biochemical } \\
\text { changes such as protein, lipid and nucleic acid } \\
\text { structures }\end{array}$ & In vitro & [111] \\
\hline $\begin{array}{l}\text { Phosphatidylcholine (PC), } \\
\text { Phosphatidylethanolamine (PE), } \\
\text { Lysophosphatidylcholine (LPC) and } \\
\text { phosphatidylinositol (PI) as major } \\
\text { Phospholipids }\end{array}$ & $\begin{array}{l}\text { 5mg/kg of } \\
\text { encapsulated } \\
\text { etoposide into } \\
\text { liposomes composed } \\
\text { of camel milk } \\
\text { phospholipids. }\end{array}$ & $\begin{array}{l}\text { Fibrosarcoma } \\
\text { (Topisomerasell) }\end{array}$ & $\begin{array}{l}\text { increasing the anticancer efficacy of } \\
\text { etoposide, encapsulated with PE-containing } \\
\text { liposomes }\end{array}$ & In vitro & [132] \\
\hline Phospholipids & $\begin{array}{l}5 \mathrm{mg} / \mathrm{kg} \text { of each } \\
\text { formulation: CML-Lip- } \\
\text { Dox; CML-Lip-ETP; } \\
\text { CML-Lip-(Dox+ETP) }\end{array}$ & Fibrosarcoma & $\begin{array}{l}\text { Antitumor activity/Dox and ETP loaded into } \\
\text { CML-Lip showed increased survival and } \\
\text { reduced tumor growth }\end{array}$ & In vivo & [133] \\
\hline $\begin{array}{l}\text { Phosphatidylethanolamine } \\
\text { (PE) }\end{array}$ & $\begin{array}{l}30-50 \mu \mathrm{l} / \mu \mathrm{g} \\
\mathrm{PE} \text { liposomes } \\
\text { encapsulating cisplatin }\end{array}$ & Melanoma & $\begin{array}{l}\text { Cytotoxic effects/PE liposomes were efficient } \\
\text { delivery for cisplatin targeting melanomas } \\
\text { and it maintained concentration of cisplatin in } \\
\text { tumour for } 72 \mathrm{~h}\end{array}$ & $\begin{array}{l}\text { In vitro } \\
\text { and In } \\
\text { vivo }\end{array}$ & [134] \\
\hline$\alpha$-Lactalbumin ( $\alpha$-La) & $\begin{array}{l}2-40 \mu \mathrm{M} \alpha \text {-La with } \\
\text { oleic acid or linoleic } \\
\text { acid }\end{array}$ & $\begin{array}{l}\text { human prostate cancer cells } \\
\text { (DU145) }\end{array}$ & $\begin{array}{l}\text { Cytotoxic effect } \\
\text { Inhibition of proliferation }\end{array}$ & & [138] \\
\hline $\begin{array}{l}\text { Camel lactoferrin (cLf), N- and C-lobes } \\
\text { lactoferrin }\end{array}$ & 0.5 and $1.0 \mathrm{mg} / \mathrm{ml}$ & Huh 7.5 cells & $\begin{array}{l}\text { cLf and C-lobe but not N-lobe have cytotoxic } \\
\text { effects }\end{array}$ & In Vitro & [139] \\
\hline $\begin{array}{l}\text { Camel antibody's single domain fragments } \\
\text { (cAb-Lys2 \& cAb-Lys3) univalent or } \\
\text { bivalent format }\end{array}$ & $10 \mu \mathrm{g} / \mathrm{ml}$ & $\begin{array}{l}\text { BW-Li \& 3LL-R variants } \\
\text { derived from BW5147 T-cell } \\
\text { lymphoma \&Lewis Lung } \\
\text { carcinoma respectively }\end{array}$ & $\begin{array}{l}\text { Non-immunogenic, rapid pharmacokinetic } \\
\text { clearance and specifically target solid tumors } \\
\text { and metastatic lesions }\end{array}$ & In vitro & [141] \\
\hline $\begin{array}{l}\text { CAR-T cells expressed camelid single } \\
\text { domain antibody }\end{array}$ & $10^{7}$ cells/mouse & $\begin{array}{l}\text { CEACAM6-expressing } \\
\text { pancreatic cell line BxPC3 }\end{array}$ & $\begin{array}{l}\text { Reduced cell viability } \\
\text { growth inhibition }\end{array}$ & In vivo & [142] \\
\hline Antibodies & $\begin{array}{l}\text { EC50 of } 10 \mathrm{pmol} / \mathrm{L} \\
100 \mu \mathrm{g} \text { of human } \\
\text { PBMCs and bsFab } \\
\text { C21 }\end{array}$ & $\begin{array}{l}\text { human ovarian carcinoma } \\
\text { (SKOV3-CEA), colon } \\
\text { carcinoma (LS174T), } \\
\text { pancreatic (BXPC3, HT29) } \\
\text { cancers }\end{array}$ & $\begin{array}{l}\text { Antibody-dependent NK cell-mediated } \\
\text { cytotoxicity } \\
\text { Tumor growth inhibition }\end{array}$ & $\begin{array}{l}\text { In vitro } \\
\text { In vivo }\end{array}$ & [143] \\
\hline $\mathrm{ZnO} \mathrm{NP}$ & & $\begin{array}{l}\text { Leukemia and lymphoma } \\
\text { (T-cell cancer lines) leukemic } \\
\text { and Hut-78 lymphoma T cell } \\
\text { lines) }\end{array}$ & $\begin{array}{l}\text { Induction of apoptosis } \\
\text { Inhibition of proliferation }\end{array}$ & In Vitro & [146] \\
\hline $\begin{array}{l}\text { Intercalation of Hippuric acid } \\
\text { nanocomposite (hippuric acid with ZLH/ } \\
\text { HAN) with doxorubicin and Oxaliplatin }\end{array}$ & & $\begin{array}{l}\text { Breast cancer and colon } \\
\text { cancer (MCF-7, MDA MB231, } \\
\text { Caco2) }\end{array}$ & Cytotoxicity/suppression of cell proliferation & In vitro & [148] \\
\hline
\end{tabular}

Table 2: In vitro and In vivo experimental studies on therapeutic properties of camel milk and urine nanoparticles against various cancer cells and cell lines.

\section{Development Efforts on Camel Products Based Anti- Cancer Nanoparticles}

NPs can be utilized for cancer therapy in various forms, including conjugated with antigens, encapsulate antigens/peptides/DNA and labeled in fluorescent, and thereby can trigger and manipulate different signaling mechanisms. NPs used for such matters are mostly designed to be drug-compatible, biocompatible, biodegradable, and easy to process, efficient in loading and controlling drug release [125]. In addition, modern developments in polymeric nano-formulations involve a number of homo and co-polymer combinations pertaining for sustained and controlled delivery of anti-cancer agents [126-131].

Various phospholipids of camel milk, including PE, PC, LPC and PI have been demonstrated for application of cancer therapy (Table 2) 
[132-134]. Liposomes prepared from these phospholipids were used as drug delivery systems for various anticancer drugs, and have shown promising anticancer activity in the murine/mouse model. Etoposide entrapped in camel milk phospholipid liposomes has showed greater anticancer activity against fibrosarcoma in a murine model compared to free etoposide or etoposide entrapped in 1,2-Dipalmitoyl-snglycero-3-phosphatidylcholine (DPPC) liposomes [132]. Combination of doxorubicin (Dox) and etoposide (ETP) loaded into camel milk phospholipids liposomes (CML-Lip) is found also to increase survival and to reduce tumor growth in the mice than the combination of Dox and ETP in DPPC-Lip [133]. The presence of PE in camel milk phospholipid liposomes could play important role in increasing the anticancer efficacy of etoposide.

Liposomes comprised of a variety of lipid molecules with high proportion of PC and cholesterol being mostly prepared for cisplatin offered low cisplatin encapsulation and drug loading efficiencies. On the other hand, camel milk's PE liposomes overcome such limitations. PE liposomes significantly promote the entrapment efficiency of cisplatin; reduce the vesicle size, target delivery and offer controlled cisplatin release. Incorporation of polyethylene glycol (PEG) derivatives in PE liposomes further enhances its cytotoxicity. Toxicity to normal cells has been reported with commonly used cationic liposomes such as DOTAP, but PE liposomes with negative surface charges overcome such drawback (Table 2) [134-137].

Camel proteins are unique that they able to maintain a high degree of thermal stability and remain functional even at elevated temperatures. Their extraordinary stability is attributable to efficient refolding after chemical or thermal denaturation and increased resistance against denaturation [138]. At high temperature $\left(60^{\circ} \mathrm{C}\right)$, camel milk $a$-lactalbumin and its complexes combined with oleic acid and linoleic acid can have a stable structure, and exhibit a cytotoxic effect on a human prostate cancer cell even after exposure to such temperature [138]. It is known that camels Lactoferrin (cLF) possess supreme immunoregulatory and anti-cancer effect. Further investigation on evaluating entailed cLF active component indicates that it's C-lobe but not N-lobe has shown significant cytotoxic effect (Table 2) [139].

The use of convectional antibodies, owning both heavy and light chains in the variable region, and cloned single domain antibodies as delivery tools for diagnostic and therapeutic purpose remain very challenging. This is mainly attributed to; loss of stability, sticky nature of rendered $\mathrm{VH}$ hydrophobic portion and subsequent difficulties on handling [140]. Camel milk antibodies naturally possess single-domain antigen-binding units. The variable domains of these camel heavychain antibodies (VHHs) show a high sequence homology to human VHs. Moreover, specific mutations in the framework 2 region of the variable domain of camel VHH make it less hydrophilic [140]. Such features of VHHs overcome the problems of stickiness encountered with conventional VH. Further, camel single VHH domains are nonimmunogenic molecules that exhibit a rapid pharmacokinetic clearance and specifically target solid tumors and metastatic lesions [141]. Camel antibodies also recognize and bind on the surface of inorganic material $[142,143]$. Such property together with the ease to produce functional and stable $\mathrm{cAb}$ constructs and their ability to recognize epitopes which are less antigenic for conventional antibodies [144,145], has offered unique advantages when targeting tumors for diagnostic or therapeutic purposes [141].

Accordingly, numerous of camel urine compounds have been also used for such applications. Notably, multifunctional zinc oxide $(\mathrm{ZnO})$ is used in various forms such as NPs or nanorods for biomedical applications including biosensing, imaging, drug delivery, and clinical implants $[113,114,146]$ the additive or synergistic effects of $\mathrm{ZnO}$ NPs with anti-cancer compounds (or drugs) was found to upregulate induction of apoptosis in cancer cells [147]. Hippuric acid nanocomposite (HAN) (a preparation from hippuric acid (HA) and $\mathrm{ZnO}$ ) combination with doxorubicin and/or with oxaliplatin induce suppression of cell proliferation and exhibit supreme cytotoxicity in several cancer cell lines as compared to individual effects. Importantly, the nanocomposite entails the drugs to reach the tumor cell membrane without early decomposition and the intercalation reaction enhances the permeability of the drug into the target cell without any noticeable side effects (Table 2) $[148,149]$.

\section{Conclusion and Future Perspectives}

Camel products and byproducts are important sources of many natural agents used for various medical applications. Despite owing remarkable therapeutic agents, scientific research in this area remains at young stage. Prominent gap is evident in regards to advanced research geared towards identifying and designing suitable nanomaterials. Meanwhile, multifunctional proteins, lipids and inorganic compounds of such natural products deemed capable of carrying both therapeutic and diagnostic agents are now being explored for more effective cancer management. Hence, additional study entailing to identify active agents, and formulation of toxicology on existing nano-materials in humans still needs to be fully studied and evaluated as studies conducted thus far have been small and limited to shortterm exposure. Investigation on nano-toxicity and nano-therapy should be intended on long-term exposure in humans, animals and the environment. By critically understanding nanomaterial's behaviors in the tumor microenvironment and their molecular characteristics as well as formulations of cloned molecules, rapid discovery of large numbers of safe and high-potency nano-materials for cancer therapy can be achieved.

\section{References}

1. Ferlay J, Soerjomataram I, Ervik M, Dikshit R, Eser S, et al. (2013) Cancer incidence and mortality worldwide: sources, methods and major patterns in GLOBOCAN 2012. Int J Cancer 136: E359-386.

2. Hanahan D, Weinberg RA (2011) Hallmarks of cancer: The next generation Cell 144: 646-674.

3. Tsai CJ, Nussinov R (2013) The molecular basis of targeting protein kinases in cancer therapeutics. Semin Cancer Biol 23: 235-242.

4. Sarkar S, Horn G, Moulton K, Oza A, Byler S, et al. (2013) Cancer development, progression, and therapy: An epigenetic overview. Int J Mol Sci 14: 21087 21113.

5. Hu YF, Russo IH, Russo J (2000) Prevention of human breast cancer. J Women's Cancer In press.

6. Pike MC, Spicer DV, Dahmoush L, Press MF (1993) Estrogens, progestogens normal breast cell proliferation, and breast cancer risk. Epidemiol Rev 15: 17-35.

7. Coufal M, Maxwell MM, Russel DE, Amore AM, Altmann SM, et al. (2007) Discovery of novel small-molecule targeting selective clearance of mutant hunting in fragments. J Biomol Screen 12: 351-360.

8. Widodo N, Kaur N, Shrestha BG, Takagi Y, Ishii T, et al. (2007) Selective killing of cancer cells by leaf extract of ashwagandha: Identification of a tumorinhibitory factor and the first molecular insights to its effect. Clin Cancer Res 13: 2298-2306

9. Khorshid FA, Shazly H, Al-Jefery A, Osman AA (2010) Dose escalation phase study in healthy volunteers to evaluate the safety of a natural product PM 701 Int J pharm Toxic 5: 91-97.

10. Grever M, Chabner B (1997) Cancer drug discovery and development in cancer propels and practice of oncology. cytotoxicity of some medical plant extract used in tanzanian traditional medicine. J Ethnopharmacol 70: 143-149. 
Citation: Alebie G, Yohannes S, Worku A (2017) Therapeutic Applications of Camel's Milk and Urine against Cancer: Current Development Efforts and Future Perspectives. J Cancer Sci Ther 9: 468-478. doi: 10.4172/1948-5956.1000461

11. Moshref SS (2007) PM 701 A highly selective anti-cancerous against 11210 leukemic cells ii in vivo clinical and histopathological study. JKAU Med Sci 14: 85-99.

12. Rood BR, Macdonald TJ, Packer RJ (2004) Current treatment of medulloblastoma: recent advances and future challenges. Semin Oncol 31: 666-675

13. Rossi A, Caracciolo V, Russo G, Reiss K, Giordano A (2008) Medulloblastoma: from molecular pathology to therapy. Clin Cancer Res 14: 971-976.

14. Craig WJ (1997) Phytochemicals: guardians of our health. J Am Diet Assoc 97: 199-204

15. Craig W, Beck L (1999) Phytochemicals: health protective Effects. Can J Dietetic Pract Res 60: 78-84.

16. Alghamdi Z, Khorshid F (2012) Cytotoxicity of the urine of different camel breeds on the proliferation of lung cancer cells, A549. J Nat Sci Res 2: 5

17. Kontou N, Psaltopoulou T, Panagiotakos D, Dimopoulos MA, Linos A (2011) The mediterranean diet in cancer prevention: a review. J Med Food 14: 1065-1078.

18. Yagil R (1982) Camels and camel milk. Food and Agriculture Organization, Anim Prod. Health Paper 26.

19. Hansen M, Fernandes G, Good R (1982) Nutrition and Immunity: The influence of diet on autoimmunity and the role of zinc in the immune response. Annu Rev Nutr 2: 151-157.

20. El Agamy El, Ruppanner R, Ismail A, Champagne CP, Assaf R (1992) Antibacterial and antiviral activity of camel milk protective proteins. J Dairy Res 59: $169-175$

21. Harrison RA, Oliver J, Hasson SS (2003) Novel sequences encoding venom C-type lectins are conserved in phylogenetically and geographically distinct Echis and Bitis viper species. Gene 315: 95-102.

22. Salwa M, Khogali E, Mohamed OY, Elhassan AM, Shammat AM, et al. (2009) Hepatoprotective effect against carbontetrachloride induced hepatotoxicity in rats. J Sci Techn 10: 128-134.

23. Alhaider AA, El Gendy MA, Korashy HM, El-Kadi AO (2011) Camel urine inhibits the cytochrome P450 1a1 gene expression through an AhR- dependent mechanism in Hep1c1c7 cell line. J Ethnopharmacol 133: 184-190.

24. Bertino J Jr1, Fish D (2000) The safety profile of the fluoroquinolones. Clin Ther 22: $798-817$

25. Leitner JM1, Graninger W, Thalhammer F (2010) Hepatotoxicity of antibacterials: Pathomechanisms and clinical. Infection 38: 3-11.

26. Sabir JSM, AbuZinadah OA, Bora RS, Ahmed MM, Saini KS (2013) Role of toxicogenomics in the development of safe, efficacious and novel anti-microbial therapies. Infect Disord Drug Targets 13: 206-214.

27. Liguori MJ, MAnderson MJ, Bukofzer S, McKim J, Pregenzer JF, et al (2005) Microarray analysis in human hepatocytes suggests a mechanism for Hepatotoxicity induced by Trovafloxacin. Hepatol 41: 177-186.

28. Thukral SK, Nordone PJ, Hu R, Sullivan L, Galambos E, et al. (2005) Prediction of nephrotoxicant action and identification of candidate toxicity-related biomarkers. Toxicol Pathol 33: 343-355.

29. Guengerich FP1 (2011) Mechanisms of drug toxicity and relevance to pharmaceutical development. Drug Metab Pharmacokinet 26: 3-14.

30. Yagil R, Saran A, Etzion Z (1984) Camels' milk: for drinking only? Comp Biochem Physiol A Comp Physiol 78: 263-266.

31. Korhonen H, Pihlanto A (2011) Food-derived bioactive peptides opportunities for designing future foods. Curr Pharm Des 9: 1297-1308.

32. Read BE (1925) Chemical constituents of camel's urine. J Biol Chem 64: 615-617.

33. Khorshid FA, Rabah SO, HAbuaraki A, Ali A, Noor SO, et al. (2015) Safety of Oral Administration of PMF a Fraction Derived From Camel Urine: Acute Study on Mice. Int J Emerg Technol Adv Eng 5: 6.

34. Rabah S, Khorshid F, Aboarik H, Hajrah N, Sabir J, et al. (2005) Safety profile of PMF a fraction derived from camel urine on mice (acute study). Energy Environ Mater Sci 978: 352-8.

35. Khorshid FA (2008) Preclinical evaluation of PM 701 in experimental animals Int J Pharmacol 4: 443-451.
36. Korashy HM, El Gendy MA, Alhaider AA, ElKadi AO (2012) Camel milk modulates the expression of aryl hydrocarbon receptor-regulated genes, Cyp1a1, Nqo1, and Gst1a2, in murine hepatoma hepa 1c1c7 cells. J Biomed Biotechnol 10.

37. El Miniawy FMH, Kawkab AA, Tony MA, Mansour SA, Khattab MMS (2014) Came milk inhibits murine hepatic carcinogenesis, initiated by diethylnitrosamine and promoted by phenobarbitone. Int J Vet Sci Med 2: 136-141.

38. Habiba HM, Ibrahim WH, Schneider-Stock R, Hassan HM (2013) Came milk lactoferrin reduces the proliferation of colorectal cancer cells and exerts antioxidant and DNA damage inhibitory activities. Food Chem 141: 148-152.

39. Khorshid FA, Moshref SS, Heffny N (2005) An Ideal Selective Anticancer Agent In Vitro, I- Tissue Culture Study of Human Lung Cancer Cells A549. JKAU-Med Sci 12: 3-18.

40. Khorshid FA, Moshref SS (2006) In Vitro Anticancer Agent, I - Tissue Culture Study of Human Lung Cancer Cells A549 II - Tissue Culture Study of Mice Leukemia Cells L1210. Int J Cancer Res 2: 330-344.

41. Moshref SS, Khorshid FA Jamal Y (2006) The Effect of PM 701 on Mice Leukemic Cells: I - Tissue Culture Study of L1210 (In Vitro) II - In Vivo Study on Mice. JKAU-Med Sci 13: 3-19.

42. Khorshid FA, Osman AA, Abdulsattar E (2009) Cytotoxicity of Bioactive fractions from PM 701. EJEAF CHE 8: 1091-1098.

43. Fkhorshid A (2009) Potential Anticancer Natural Product against Human Lung Cancer Cells. Trends Med Res 4: 9-15.

44. Raouf GA, Khorshid FA, Kumosani T (2009) FT-IR Spectroscopy as a Too for Identification of Apoptosis-Induced Structural Changes in A549 Cells Dry Samples Treated with PM 701. Int J Nano Biomaterials 2: 396-408.

45. Ahmed GA, Khorshid FA, Kumosani TA (2010) FT-IR Spectroscopy of A549 Cells Treated with PMF: Structural changes in DNA and cell membrane. Thoracic Oncol 5: 46S

46. Khorshid F (2011) The Cytotoxic effect of PM 701 and its fractions on cell proliferation of breast cancer cells, McF7. Am J Drug Discov Dev.

47. Khorshid FA, Alameri JS (2011) Apoptosis Study on the Effect of PMF on Different Cancer Cells. Int J Biol Chem.

48. Ali A, Aboarky H, Khorshid F (2011) Tumor Model for Assessing Antineoplastic Effect of Camel's Urine Fraction (PMF) in Rodent's Lung Cancer: Histopathological Study. Trends Appl Sci Res 6: 1214-1221.

49. Korashy HM, Maayah ZH, Abd-Allah AR, El-Kadi AOS, Alhaider AA (2012) Camel milk triggers apoptotic signaling pathways in human hepatoma HepG2 and breast cancer MCF7 cell lines through transcriptional mechanism. J Biomed Biotechnol 9: 2012

50. Al-Yousef N, Gaafar A, Al-Otaibi B, Al-Jammaz I, Al-Hussein K, et al. (2012) Camel urine components display anti-cancer properties in vitro. J Ethnopharmacol.

51. Mahboub FA, Khorshid FA, Emwas AM (2014) The Cytotoxic Effect of Smal and Large Molecules of PMF Fraction Extracted from Camel Urine on Cance Cells. Brit J Med Med Res 6.

52. Jeuken A, Keser BJ, Khan E, Brouwer A, Koeman J, et al. (2003) Activation of the Ah receptor by extracts of dietary herbal supplements, vegetables, and fruits. J Agr Food Chem 51: 5478-5487.

53. Korashy HM, El-Kadi AOS (2005) Regulatory mechanisms modulating the expression of cytochrome P450 1A1 gene by heavy metals. Toxicol Sci 88 : 39-51.

54. Werlinder V, Backlund M, ZhukovA, IngelmanSundberg M (2001) Transcriptiona and post-translational regulation of CYP1A1 by primaquine. J Pharmacol Exp Ther 297: 206-214

55. Kikuchi G, Yoshida T, Noguchi M (2005) Heme oxygenase and heme degradation. Biochem Biophys Res Commun 338: 558-567.

56. Mohora M (2000) Role of $\mathrm{Nad}(\mathrm{P}) \mathrm{h}$ : quinone oxidoreductase in the regulation of intracellular redox state. Romanian J Intern Med 38-39: 33-50.

57. Danson S, Ward TH, Butler J, Ranson M (2004) DTdiaphorase: a target for new anticancer drugs. Cancer Treat Rev 30: 437-449.

58. Farah Z, Rettenmaier R, Atkins D (1992) Vitamin content of camel milk. Int J Vitamin Nutr Res 62: 30-33. 
Citation: Alebie G, Yohannes S, Worku A (2017) Therapeutic Applications of Camel's Milk and Urine against Cancer: Current Development Efforts and Future Perspectives. J Cancer Sci Ther 9: 468-478. doi: 10.4172/1948-5956.1000461

59. Konuspayeva G, Faye B, Loiseau G, Levieux D (2007) Lactoferrin and immunoglobulin contents in camel's milk (Camelus bactrianus, Campus dromedarius, and Hybrids) from Kazakhstan. J Dairy Sci 90: 38-46.

60. Krishna G, Nath J, Ong T (1986) Inhibition of cyclophosphamide and mitomycin-C induced sister chromatid exchanges in mice by vitamin $\mathrm{C}$. Cancer Res 46: 2670-2674.

61. Castillo J, Benavente-Garci'a O, Lorente J, Alcaraz M, Redondo A, et al (20004) Antioxidant activity and radio protective effects against chromosomal damage induced in vivo by X-rays of flavan-3-ols (Procyanidins) from grape seeds (Vitis vinifera): comparative study versus other phenolic and organic compounds. J Agr Food Chem 8: 1738-1745

62. Aly FA, Donya $S(2000)$ In vivo antimutagenic effect of vitamins $C$ and $E$ against rifampicin-induced chromosomal aberrations in mouse bone-marrow cells. Mutat Res 518: 1-7.

63. Rao MV (1997) Mercury and its effects on mammalian system - a critica review. Indian J Environ Toxicol 7: 3-11.

64. Sato K, Kusaka Y, Zhang Q, Deguchi Y, Li B, et al. (1997) Direct effect of inorganic mercury on citrate uptake by isolated rat renal brush border membrane vesicles. Ind Health 35: 456-460

65. Herbaczyn'ska CK, Ktosiewicz WB, Cedro K, Wasek W, Panczenko KB, et al (1999) Supple-mentation with vitamins $C$ and $E$ suppresses leukocyte oxygen free radical production in patients with myocardial infarction. Eur Health $\mathrm{J} 16$ 1044-1049.

66. Hurná E1, Hurná S (2000) Protective effect of zinc on cadmium-induced micronuclei in V79 cells. J Trace Elem Med Biol 14: 55-57.

67. Hurna' E, Siklenka P, Hurna' S (1997) Effect of selenium on cadmium genotoxicity investigated by micronucleus assay. Vet Med Czech 42: 339-342.

68. Hassan NH, Fahmy MA, Farghaly AA, Hassan EE (2006) Anti-mutagenic effect of selenium and vitamins against the genotoxicity by cobalt chloride in mice. Cytologia 71: 213-222.

69. Ianas O, Olinescu R, Badescu I, Simionescu L, Popovici D (1995) The influence of "selenium organicum" upon the hepatic function of carbon tetrachloride poisoned rats. J Int Med 33: 113-120.

70. Bosselaers IE, Caessens PW, Van Boekel MA, Alink GM (1999) Differential effects of milk proteins, BSA and soy protein on 4NQO- or MNNG-induced SCEs in V79 cells. Food Chem Toxicol 32: 905-909.

71. Van Boekel MA, Weerens CN, Holstra A, Scheidtweiler CA, Alink GM (1993) Antimutagenic effects of casein and its digestion products. Food Chem Toxicol 31: 731-737

72. Goeptar AR, Koeman JH, Van Boekel MA, Alink MA (1997) Impact of digestion on the antimutagenic activity of the milk protein casein. Nutr R 17: 1363-1379.

73. Al-Majali AM, Bani Ismail Z, Al-Hami Y, Nour AY (2007) Lactoferrin concentration in milk from camel (Camelus dromedarius) with and without subclinical mastitis. Int J Appl Res Vet Med 5: 120-124.

74. Sekine K, Watanabe E, Nakamura J (1997) Inhibition of azoxymethane-initiated colon tumor by bovine lactoferrin administration in F344 rats. Jpn J Cancer Res 88: $523-526$

75. Masuda C, Wanibuchi $\mathrm{H}$, Sekine $\mathrm{K}$ (2000) Chemopreventive effects of bovine lactoferrin on $\mathrm{N}$-butyl-N-(4-hydroxybutyl)nitrosamineinduced rat bladder carcinogenesis. Jpn J Cancer Res 91: 582-588.

76. Bezault J, Bhimani R, Wiprovnick J, Furmanski P (1994) Human lactoferrin inhibits growth of solid tumors and development of experimental metastases in mice. Cancer Res 54: 2310-2312.

77. Varadhachary A, Wolf JS, Petrak K (2004) Oral lactoferrin inhibits growth of established tumors and potentiates conventional chemotherapy. Int $\mathrm{J}$ Cancer 111: 398-403.

78. Norrby K, Mattsby-Baltzer I, Innocenti M, Tuneberg S (2001) Orally administered bovine lactoferrin systemically inhibits VEGF(165)-mediated angiogenesis in the rat. Int J Cancer 91: 236-240.

79. Badr El-Din NK, Omaye ST (2007) Concentration dependent antioxidant activities of conjugated Linoleic acid anda-tocopherol in corn oil. Br J Nutr 60: 32-37

80. Liew C, Schut HA, Chin SF, Pariza MW, Dashwood RJ (1995) Protection of conjugated linoleic acids against 2-amino-3- methyl-imidazo [4,5-f] quinoline- induced colon carcinogenesis in the F344 rat: a study of inhibitory mechanisms. Carcinogenesis 16: 3037-3043

81. Yang H, Stuart G, Glickman BW, de Boer JG (2001) Modulation of 2-amino1-methyl-6-phenylimidazo[4,5-b] pyridineinduced mutation in the cecum and colon of big blue rats by conjugated linoleic acid and 1,2-dithiole-3-thione. Nutr Cancervol 39: 259-266

82. Cabrera C, Jime'nez R, Lopez C (2003) Determination of tea component with antioxidant activity. J Agr Food Chem 51: 4427-4435.

83. Vecchione A, Croce CM (2010) Apoptomirs: small molecules have gained the license to kill. Endocrine Related Cancer 17: F37-F50.

84. Tsang WP, Chau SPY, Kong SK, Fung KP, Kwok TT (2003) Reactive oxygen species mediate doxorubicin induced p53-independent apoptosis. Life Sci 73: 2047-2058.

85. Lowe SW, Lin AW (2000) Apoptosis in cancer. Carcinogenesis 21: 485-495.

86. Herr 11, Debatin KM (2001) Cellular stress response and apoptosis in cancer therapy. Blood 98: 2603-2614.

87. Hickman JA (1992) Apoptosis induced by anticancer drugs. Cancer Metast Rev 11: $121-139$

88. Sidgi Hasson SA, Al-Busaidi JZ, Al-Qarni AM, Al-Bahlani RS, Idris MA, et al. (2015) In Vitro Apoptosis Triggering in the BT-474 Human Breast Cancer Cell Line by Lyophilised Camel's Milk. Asian Pac J Cancer Prev 16: 6651-6661.

89. Almahdy O, EL-Fakharany EM, EL-Dabaa E, Ng TB, Redwan EM (2011) Examination of the Activity of Camel Milk Casein against Hepatitis C Virus (Genotype-4a) and Its Apoptotic Potential in Hepatoma and HeLa Cell Lines. Hepat Mon 11: 724-730.

90. Bian J, Wang K, Kong X (2011) Caspase- and p38-MAPKdependent induction of apoptosis in A549 lung cancer cells by Newcastle disease virus. Arch Virol 8: $1335-1344$.

91. Guyton KZ, Spitz DR, Holbrook NJ (1996) Expression of stress response genes GADD153, c-jun, and heme oxygenase-1 in H2O2- and O2-resistant fibroblasts. Free Radical Biol Med 20: 735-741.

92. Herr I, Debatin KM (2001) Cellular stress response and apoptosis in cancer therapy. Blood 98: 2603-2614.

93. Fujita K, Matsuda E, Sekine K, ligo M, Tsuda H (2004) Lactoferrin enhances Fas expression and apoptosis in the colon mucosa of azoxymethane-treated rat. Carcinogenesis 25: 1961-1966.

94. Adlerova L, Bartoskova A, Faldyna M (2008) Lactoferrin: A review. Veterinarn Medicina 9: 457-468

95. Campbell T, Skilton RA, Coombes RC, Shousha S, Graham MD, et al. (1992) Isolation of a lactoferrin cDNA clone and its expression in human breast cancer. $\mathrm{Br} J$ Cancer 65: 19-26.

96. Damiens E, Yazidi IE, Mazurier J, Duthille I, Spik G (1997) Lactoferrin inhibits G1 cyclin-dependent kinases during growth arrest of human breast carcinoma cells. J Cell Biochem 74: 486-498.

97. Baumrucher CR, Gibson CA, Schanbacher FL (2003) Bovine lactoferrin binds to insulin-like growth factor-binding protein 3. Domest Anim Endocrinol 24: 287-303.

98. Maier B1, Gluba W, Bernier B, Turner T, Mohammad K, et al. (2004) Modulation of mammalian life span by the short isoform of p53. Genes Dev 18: 306-319.

99. Lacroix M1, Toillon RA, Leclercq G (2006) p53 and breast cancer, an update. Endocr Relat Cancer 13: 293-325.

100. Adams WC, Bond E, Havenga MJ, Holterman L (2009) Adenovirus serotype 5 infects human dendritic cells via a coxsackievirusadenovirus receptor independent receptor pathway mediated by lactoferrin and DC-SIGN. J Gen Virol 90: 1600-1610.

101. Sanchez L, Ismail M, Liew FY, Brock JH (1999) Iron transport across Caco2 cell monolayers. Effect of transferrin, lactoferrin and nitric oxide. Biochim Biophys Acta 1289: 291-297.

102. Evers JM, Haverkamp RG, Holroyd SE, Jameson GB, Mackenzie DDS, et al. (2008) Heterogeneity of milk fat globule membrane structure and composition as observed using fluorescence microscopy techniques. Int Dairy J 18: 1081-1089.

103. Harmsen MM, De Haard HJ (2007) Properties, production and applications of camelid single-domain antibody fragments. Appl Microbiol Biotechnol 77: $13-22$. 
Citation: Alebie G, Yohannes S, Worku A (2017) Therapeutic Applications of Camel's Milk and Urine against Cancer: Current Development Efforts and Future Perspectives. J Cancer Sci Ther 9: 468-478. doi: 10.4172/1948-5956.1000461

104. Cortez RV, Lauwereys M, Hassanzadeh GG, Gobert M, Conrath K, et al. (2002) Efficient tumor targeting by single-domain antibody fragments of camels. Int J Cancer 98: 456-462.

105. Al-Fartosi KG, Khuon OS, Al-Tae HI (2011) Protective role of camel's milk against paracetamol induced hepatotoxicity in male rats. Int $\mathrm{J}$ Res Pharm Biomed Sci 2: 1795-1799.

106. Hamad EM, Abdel-Rahim EA, Romeih EA (2011) Beneficial effect of camel milk on liver and kidneys function in diabetic sprague-dawley rats. Int J Dairy Sci 6: 190-197.

107. Mohamed EMA(2010) Effect of camel's milk on cisplatin-induced nephrotoxicity in Swiss Albino mice. Am J Biochem Biotech 6: 141-147.

108. Ahmed GAR, Khorshid FA, Khedr A, El-Hamidy SM, Salah NA (2015) The effect of PMF Camel Urine Nanoparticles on A549 Cells: The Mechanism of Action and Drug Delivery. Life Sci J 12.

109. Ahmed GAR, Khorshid FA, Khedr A, El-Hamidy SM, Salah (2015) The Mechanism of PMF Nanoparticles in Invading A549 cells, A New Selective Drug Delivery for Cancer Therapy. New Developments in Biology, Biomedical \& Chemical Engineering and Materials Science.

110. El-Shahawy A, El-Sawi N, Backer WS, Khorshid FA, Geweely NS (2010) Spectral Analysis, Molecular Orbital Calculations And Antimicrobial Activity Of PMF-G Fraction. Int J Pharm Biosci 1: 1-19.

111. Faten AK, Gehan AR, Salem ME, Gehan SA, Nourah AA, et al. (2011) PMF Cesium \& Rubidium Nanoparticles Induce Apoptosis in A549 Cells. Life Sci J 8: 534-542.

112. Dan P, Jeffrey MK, Seungpyo H, Omid CF, Rimona M, et al. (2007) Nanocarriers as an emerging platform for cancer therapy. Nat Nanotechnol 2: 751-760.

113. De Berardis B, Civitelli G, Condello M, Lista P, Pozzi R, et al. (2010) Exposure to $\mathrm{ZnO}$ nanoparticles induces oxidative stress and cytotoxicity in human colon carcinoma cells. Toxicol Appl Pharmacol 246: 116-127.

114. Huang CC, Aronstam RS, Chen DR, Huang YW (2010) Oxidative stress, calcium homeostasis, and altered gene expression in human lung epithelia cells exposed to $\mathrm{ZnO}$ nanoparticles. Toxicol In Vitro 24: 45-55.

115. AshaRani PV, Low Kah Mun G, Hande MP, Valiyaveettil S (2009) Cytotoxicity and genotoxicity of silver nanoparticles in human cells. ACS Nano 3: 279-290.

116. Yang Z, Xie C (2006) Zn 2+ release from zinc and zinc oxide particles in simulated uterine solution. Colloids Surf B Biointerfaces 47: 140-145.

117. Park SJ, Park YC, Lee SW, Jeong MS, Yu KN, et al. (2011) Comparing the toxic mechanism of synthesized zinc oxide nanomaterials by physicochemical characterization and reactive oxygen species properties. Toxicol Lett 207 197-203.

118. Li N, Xia T, Nel AE (2008) The role of oxidative stress in ambient particulate matter-induced lung diseases and its implications in the toxicity of engineered nanoparticles. Free Radical Bio Med 44: 1689-1699.

119. Brewer K (1979) Mechanism of carcinogenesis: Comments on therapy. J Int Acad Prev Med 5: 29-53.

120. Andreas G, MOliver MF, Axel U (2004) The discovery of receptor tyrosine kinases: targets for cancer therapy. Nat Rev Cancer 4: 361-370.

121. Amit A, Scholar EM (2005) Role of Tyrosine Kinase Inhibitors in Cancer Therapy. J Pharma Exp Ther 315: 971-979.

122.Paul GL, Robert DS (1998) Cancer grading by Fourier transform infrared spectroscopy. 4: 37-46.

123. Lin W, Karin A (2007) cytokine-mediated link between innate immunity, inflammation, and cancer. J Clin Invest 117: 1175-1183.

124. Maria M, Leslee S, Harika N, Michelle P, Fabian B (2012) Toll-Like Receptors as Novel Therapeutic Targets for Ovarian Cancer. ISRN Oncol 2012: 8.

125. Lü JM, Wang X, Marin-Muller C, Wang H, Lin PH, et al. (2009) Current advances in research and clinical applications of plga-based nanotechnology. Expert Rev Mol Diagn 9: 325-341.

126. Hwang HY, Kim IS, Kwon IC, Kim YH (2008) Tumor targetability and antitumor effect of docetaxel-loaded hydrophobically modified glycol chitosan nanoparticles. J Control 128: 23-31.

127. Benny O, Fainaru O, Adini A, Cassiola F, Bazinet L, et al. (2008) An orally delivered small-molecule formulation with antiangiogenic and anticancer activity. Nat Biotechnol 26: 799-807.

128. Kim JH, Kim YS, Park K, Kang E, Lee S, et al. (2008) Self-assembled glycol chitosan nanoparticles for the sustained and prolonged delivery of antiangiogenic small peptide drugs in cancer therapy. Biomaterials 29: 19201930.

129. Balakrishnan P, Lee BJ, Oh DH, Kim JO, Lee YI, et al. (2009) Enhanced ora bioavailability of coenzyme Q10 by self-emulsifying drug delivery systems. Int J Pharm 374: 66-72.

130.Wang A, Li S (2008) Hydroxycamptothecin-loaded nanoparticles enhance target drug delivery and anticancer effect. BMC Biotechnol 8: 46

131. Howard KA, Paludan SR, Behlke MA, Besenbacher F, Deleuran B, et al. (2009) Chitosan/sirna nanoparticle-mediated tnf-[alpha] knockdown in peritonea macrophages for anti-inflammatory treatment in a murine arthritis model. Mol Ther 17: 162-168

132. Maswadeh HM, Aljarbou AN, Alorainy MS, Alsharidah MS, Khan MA (2015) Etoposide incorporated into camel milk phospholipids liposomes shows increased activity against fibrosarcoma in a mouse model. Bio Med Res Int 2015: 11

133. Maswadeh HM, Aljarbou AN, Alorainy MS, Alsharidah MS, Khan MA (2015) Co-administration of doxorubicin and etoposide loaded in camel milk phospholipids liposomes showed increased antitumor activity in a murine model. Int J Nanomed 10: 2847-2855.

134. Hwang T, Lee W, Hua S, Fang $Y$ (2007) Cisplatin encapsulated in phosphatidylethanolamine liposomes enhances the in vitro cytotoxicity and in vivo intratumor drug accumulation against melanomas. J Dermatol Sci 46 $11-20$.

135. Drummond DC, Meyer O, Hong K, Kirpotin DB, Papahadjopoulos D (1999) Optimizing liposomes for delivery of chemotherapeutic agents to solid tumors. Pharmacol Rev 51: 691-743

136. Newman MS, Colbern GT, Working PK, Engbers C, Amantea MA (1999) Comparative pharmacokinetics, tissue distribution, and therapeutic effectiveness of cisplatin encapsulated in longcirculating, pegylated liposomes (SPI-077) in tumor-bearing mice." Cancer Chemother Pharmacol 43: 1-7

137. Xiao C, Qi X, Maitani Y, Nagai N (2004) Sustained release of cisplatin from multivesicular liposomes: potentiation of antitumor efficacy against S180 murine carcinoma. J Pharm Sci 93: 1718-1724

138. Atri SM, Saboury AA, Moosavi-Movahedi AA, Goliaei B, Sefidbakht Y, et al. (2011) Structure and Stability Analysis of Cytotoxic Complex of Came a-Lactalbumin and Unsaturated Fatty Acids Produced at High Temperature. J Biomol Struct Dynam 28: 6.

139. Redwan ME, EL-Fakharany ME, Linjawi HM (2014) Screening of the antiinfectivity potentials of native $\mathrm{N}$ - and $\mathrm{C}$-lobes derived from camel lactoferrin against Hepatitis C Virus. BMC Complement Altern Med 14: 219.

140. Muyldermans S, Atarhouch T, Saldanha J (1994) Sequence and structure of $\mathrm{VH}$ domain from naturally occurring camel heavy chain immunoglobulins lacking light chains. Protein Eng 7: 1129-1135.

141. Cortez-Retamozo V, Lauwereys M, Hassanzadeh G, Gobert M, Conrath K et al. (2002) Efficient tumor targeting by single-domain antibody fragments of camels. Int J Cancer 98: 456-462.

142. Wong WY, Tanha J, Krishnan L, Tian B, Kumar P, et al. (2016) CAR-T cells harboring a camelid single domain antibody as a targeting agent to CEACAM6 antigen in pancreatic cancer. Research Poster Presentation.

143. Rozan C, Cornillon M, Petiard C, Chartier M, Behar G, et al. (2013) SingleDomain Antibody-Based and Linker-Free Bispecific Antibodies Targeting FcgRIII Induce Potent Antitumor Activity without Recruiting Regulatory T Cells. Mol Cancer Ther 12: 1481-1491.

144. Frenken L, van der Linden RHJ, Hermans PWJ (2008) Isolation of antigenspecific llama $\mathrm{VHH}$ antibody fragment and their high level secretion by Saccharomyces cerevisiae. J Biotechnol 78: 11-21.

145. Lauwereys M, Ghahroudi A, Desmyter A (1998) Potent enzyme inhibitors derived from dromedary heavy-chain antibodies. EMBO J 17: 3512-3120.

146. Hanley C, Layne J, Punnoose A, Reddy K, Coombs I, et al. (2008) Preferential killing of cancer cells and activated human $\mathrm{T}$ cells using $\mathrm{ZnO}$ nanoparticles. Nanotechnology 19: 295-103. 
Citation: Alebie G, Yohannes S, Worku A (2017) Therapeutic Applications of Camel's Milk and Urine against Cancer: Current Development Efforts and Future Perspectives. J Cancer Sci Ther 9: 468-478. doi: 10.4172/1948-5956.1000461

147. Yuan L, Wang Y, Wang J, Xiao H, Liu X (2014) Additive effect of zinc oxide nanoparticles and isoorientin on apoptosis in human hepatoma cell line. Toxicol Lett 225: 294-304.

148. Hussein AASH, Al-Qubaisi M, Hussein MZ, Ismail M, Bullo S (2013) Hippuric acid nanocomposite enhances doxorubicin and oxaliplatin-induced cytotoxicity in MDA-MB231, MCF-7 and Caco2 cell lines. Drug Design Dev Ther 7: 25-31.

149. Choy JH, Jung JS, Oh JM (2004) Layered double hydroxide as an efficient drug reservoir for folate derivatives. Biomaterials 25: 3059-3064. 